\title{
WAKTU PENYELESAIAN PROYEK KONSTRUKSI MENGGUNAKAN PRECEDENCE DIAGRAM METHOD DAN LINE OF BALANCE
}

\author{
I Wayan Yoga Astawa ${ }^{1 \S}$, Ni Ketut Tari Tastrawati ${ }^{2}$, Luh Putu Ida Harini ${ }^{3}$ \\ ${ }^{1}$ Program Studi Matematika, Fakultas MIPA - Universitas Udayana [Email: astawayoga139@gmail.com] \\ ${ }^{2}$ Program Studi Matematika, Fakultas MIPA - Universitas Udayana [Email: tastrawati@unud.ac.id] \\ ${ }^{3}$ Program Studi Matematika, Fakultas MIPA - Universitas Udayana [Email: ballidah@gmail.com] \\ ${ }^{\S}$ Corresponding Author
}

\begin{abstract}
Project is any work that has a beginning and ending, consisting of several jobs/activities that must be carried out in a certain order. Contractors typically use the Gantt Chart Method in scheduling home construction projects so that it is difficult to know the impact caused by the late completion of work on scheduling the entire project. The purpose of this study is to determine the time needed to complete two housing units using the Precedence Diagram Method and the Line of Balance Method. The data used in this research are the dependency relationship between activities, time schedule, cost analysis plan (RAB), and SNI unit price analysis. The analysis process carried out in this study is to calculate the time needed to complete two housing units using two methods, namely the Precedence Diagram Method and the Line of Balance method. The results of this study indicate the time needed to build two housing units using the Precedence Diagram Method 7 days faster than using the Line of Balance Method.
\end{abstract}

Keywords: Precedence Diagram Method, Line of Balance, Scheduling Method.

\section{PENDAHULUAN}

Menurut Siang (2014), proyek yaitu suatu pekerjaan yang terdiri dari beberapa kegiatan yang dilakukan berdasarkan urutannya. Setiap kegiatan memerlukan sumber daya yang berbeda. Untuk menghindari pemborosan sumber daya pada suatu proyek, diperlukan manajemen proyek yang baik. Manajemen proyek yang baik yaitu melakukan perencanaan tujuan yang akan dicapai, pengawan pekerja proyek dan mengendalikan sumber daya agar tercapai tujuan yang telah ditentukan (Soeharto, 1999).

Pada umumnya metode yang digunakan oleh pengembang atau pemilik proyek dalam perencanaan atau penjadwalan proyek yaitu Metode Gantt Chart, Line of Balance (LOB), dan Network Diagram (Project Evaluation Technique (PERT), Critical Path Method (CPM), Precedence Diagram Method (PDM)). Metode Gantt Chart mudah dipahami sehingga sering digunakan sebagai time schedule dalam penyelenggaraan proyek. Namun, memiliki kekurangan yaitu tidak diketahui hubungan ketergantungan antara setiap kegiatan, sehingga sulit untuk mengetahui dampak yang diakibatkan oleh keterlambatan penyelesaian suatu kegiatan terhadap penyelesaian keseluruhan proyek dan sukar mengadakan perbaikan, karena biasanya harus dilakukan dengan membuat bagan balok baru (Soeharto, 1999). Network Diagram dianggap sebagai suatu langkah penyempurnaan metode Gantt Chart karena dapat mengetahui dampak yang terjadi jika suatu kegiatan terlambat penyelesaiannya (Soeharto, 1999).

Adapun penelitian sebelumnya yang membahas tentang penjadwalan proyek konstruksi menggunakan metode PERT/CPM dan PDM pada paket-03 proyek jalan tol Benoa-Ngurah Rai-Nusa Dua, Bali. Menurut Sugiarti (2014) pada penelitian tersebut metode PDM lebih baik digunakan daripada PERT/CPM karena waktu penyelesaian proyek lebih cepat. Selain itu terdapat pula penelitian yang membahas penjadwalan proyek konstruksi menggunakan metode PERT/CPM dan LOB 
pada pembangunan perumahan type 36/120

Kori Nuansa Bukit. Pada penelitian tersebut penjadwalan proyek untuk satu unit rumah menggunakan metode LOB lebih cepat 17 hari dibandingkan menggunakan metode PERT/CPM (Verenika, 2015).

Penelitian ini bertujuan untuk mengetahui waktu penyelesaian dua unit rumah menggunakan precedence diagram method dan metode line of balance.

\section{METODE PENELITIAN}

Sumber data pada penelitian ini penulis memperoleh dari pemilik proyek pembangunan perumahan lantai 2 type 62/245. Sumber data yang digunakan adalah data primer berupa pengisian data hubungan ketergantungan kegiatan dan data sekunder berupa informasi mengenai rancangan anggaran biaya (RAB), jadwal pelaksanaan aktivitas (time schedule), dan analisa harga satuan SNI. Tahapan analisis data yang digunakan pada penelitian ini yaitu yang pertama menggunakan Precedence Diagram Method (PDM), selanjutnya menggunakan Line of Balance (LOB),

Langkah - langkah yang dilakukan pada metode PDM yaitu:

a. Mengidentifikasi setiap kegiatan proyek;

b. Setiap kegiatan pada proyek disusun menjadi network diagram dengan menggunakan metode penggambaran AON (Activity on Node);

c. Menentukan ES (Earliest Start), LS (Latest Start), EF (Earliest Finish), dan LF (Latest Finish). Cara menentukan ES (Earliest Start) dan EF (Earliest Finish) yaitu dengan hitungan maju, sedangkan menghitung LS (Latest Start) dan LF (Latest Finish) yaitu dengan hitungan mundur;

d. Menentukan jalur kritis dimana syarat umum jalur kritis ini yaitu:

$$
\begin{aligned}
\text { i. } & E S=L S=0 \text { atau } E(1)=L(1)=0 \\
\text { ii. } & L F=E F \text { pada kegiatan terakhir } \\
\text { iii. } & \text { Float total atau } T F=0 \\
& T F=L F-E F=L S-E S
\end{aligned}
$$

iv. Jika hanya sebagian dari kegiatan bersifat kritis, maka kegiatan tersebut secara utuh dianggap kritis.

Langkah - langkah yang dilakukan pada metode LOB adalah:

a. Mengidentifikasi kegiatan- kegiatan proyek; b. Menyusun network diagram pada proyek pembangunan perumahan lantai 2 type 62/245 berdasarkan hubungan ketergantungan dari setiap aktivitas;

c. Menentukan jumlah tenaga kerja setiap aktivitas dengan rumus:

Jumlah tenaga kerja $=$ $\frac{\text { Vol. pek.kegiatan } A}{\text { durasi kegiatan } A} \times$ koef. tenaga kerja ;

d. menghitung kecepatan produksi untuk setiap kegiatan dengan 1 kelompok pekerja dengan rumus:

$$
u r_{A}=\frac{r p r_{A}}{Q_{A}}=\frac{1}{D_{A}}
$$

Keterangan (Hutagaol et al,2013):

$u p r_{A}$ : Tingkat produksi pada kegiatan $A$

$\mathrm{rpr}_{A}$ : Produktivitas tenaga kerja $A$

$Q_{A}$ : Volume pekerjaan kegiatan $A$

$D_{A} \quad$ : Rentang waktu Aktivitas $A$

e. Menentukan kelompok pekerja yang mengerjakan tiap aktivitas dengan mengelompokkan perkerjaan yang mempunyai kriteria yang sama dan merataratakan jumlah mandor pada masingmasing kelompok pekerjaan;

f. Menghitung kecepatan produksi total dengan rumus:

$$
\begin{aligned}
\text { Kecepatan produksi total } \\
=\text { kecepatan produksi } \\
\times \text { jumlah klmp }
\end{aligned}
$$

g. menentukan durasi total setiap aktivitas untuk menyelesaikan semua unit dengan rumus:

$$
\begin{aligned}
& \text { Durasi total seluruh unit } \\
& \quad=\frac{\text { jumlah unit yang dibangun }}{\text { kecepatan produksi total }}
\end{aligned}
$$

h. Menentukan waktu start dan finish setiap aktivitas dan selanjutnya dapat diketahui durasi total proyek pada setiap kegiatan;

i. Menggambarkan diagram Line of Balance (LOB).

\section{HASIL DAN PEMBAHASAN}

\subsection{Analisis dengan Metode PDM}

Penjadwalan proyek dengan PDM memiliki langkah-langkah yaitu yang pertama mengidentifikasi setiap kegiatan pada proyek, selanjutnya setiap kegiatan disusun menjadi network diagram menggunakan metode penggambaran AON berdasarkan hubungan ketergantungan dari setiap kegiatan, setelah network diagram selesai disusun dapat diketahui $E S, E F, L S$ dan $L F \quad$ dengan 
menggunakan hitungan maju dan hitungan mundur, selanjutnya dapat diketahui jalur kritis dengan menghubungkan setiap kegiatan kritis yang dilihat berdasarkan syarat umum jalur kritis.

\subsubsection{Mengidentifikasi Kegiatan pada Proyek}

Berdasarkan time schedule, diindentifikasi setiap kegiatan pada proyek yaitu dengan mengurutkan kegiatan berdasarkan waktu mulai dan mengetahui hubungan ketergantungan setiap kegiatan, karena dalam penelitian ini dibahas mengenai penjadwalan proyek dua rumah yang identik, maka kegiatan-kegiatan pada time schedule dikalikan dua.

\subsubsection{Menyusun Network Diagram AON}

Pada penyusunan network diagram menggunakan metode $\mathrm{AON}$, penyusunannya menggunakan program komputer yaitu Microsoft Project. Sebagai contoh diagram AON dapat dilihat pada gambar 1 .

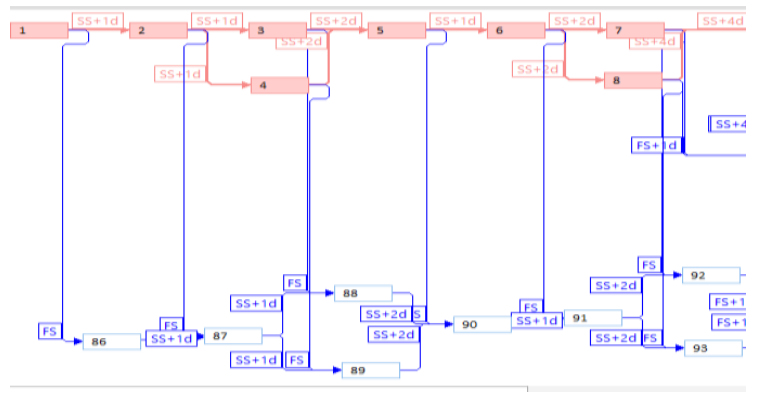

Gambar 1. Contoh Diagram AON

Angka dalam setiap node melambangkan kegiatan dalam proyek dan garis menyatakan hubungan ketergantungan dari suatu kegiatan.

\subsubsection{Menentukan $E S, L S, E F$, dan $L F$ pada PDM}

Menentukan $E S, L S, E F$ dan $L F$ pada PDM dapat dilakukan dengan dua cara yaitu hitungan maju untuk menentukan $E S$ dan $E F$ serta hitungan mundur untuk menentukan $L S$ dan $L F$. Pada hitungan maju Earliest Start (ES) kegiatan paling awal dianggap nol, sehingga hitungan untuk kegiatan $N_{1}$ yaitu,

$$
\begin{aligned}
& E S(1)=0 \\
& E F(1)=E S(1)+D(1)=0+4=4 \\
& \text { Dan Pada hitungan mundur Latest }
\end{aligned}
$$
Finish (LF) kegiatan paling akhir dianggap sama dengan Earliest Finish (EF)nya, sehingga hitungan untuk kegiatan $N_{170}$ yang dalam penelitian ini sebagai kegiatan terakhir proyek menjadi:

$$
\begin{aligned}
L F(170) & =E F(170)=150 \\
L S(170) & =L F(170)-D(170) \\
& =150-5=145
\end{aligned}
$$

\subsubsection{Menentukan Jalur Kritis}

Setelah diketahui $E S, L S, E F$ dan $L F$ dari masing-masing kegiatan, dapat diketahui jalur kritis dari penjadwalan proyek dengan melihat apakah suatu kegiatan memenuhi syarat umum jalur kritis yaitu $E S=L S, E F=L F$ dan float total atau $\mathrm{TF}=0$.

Pada penelitian ini, kegiatan- kegiatan kritis dengan menggunakan metode PDM yaitu pekerjaan pembersihan, pemasangan bowplank, galian tanah pondasi menerus, galian tanah pondasi setempat, urugan pasir dibawah pondasi, pekerjaan beton rabat dan lantai kerja 1:3:5, pekerjaan beton foot plat $1(\mathrm{Fe} 51)$, pekerjaan beton foot plat 2 ( $F e$ 52), pemasangan batu kosong, pemasangan batu kali, pekerjaan beton slooft (S1) $25 \times 30$ (Fe $118 \mathrm{~kg}$ ), pekerjaan beton slooft $(S 2) 15 \times$ $20 \quad(F e 158 \mathrm{~kg})$, pekerjaan beton kolom $(K 1) 25 \times 25$ (Fe $217 \mathrm{~kg}$ ), pekerjaan beton kolom (K2) $13 \times 13(\mathrm{Fe} 210 \mathrm{~kg})$, pekerjaan beton balok (B1) $25 \times 40(\mathrm{Fe} 176 \mathrm{~kg})$, pekerjaan beton balok (B2) $20 \times 30(\mathrm{Fe} 251 \mathrm{~kg})$, pekerjaan beton kolom (K3) $13 \times 20$ (Fe $279 \mathrm{~kg}$ ), pekerjaan beton kolom $(\mathrm{K} 4) \quad 25 \times 25(\mathrm{Fe} 151 \mathrm{~kg})$, pekerjaan beton kolom (K5) $13 \times 20$ (Fe $288 \mathrm{~kg}$ ), pekerjaan beton balok (B3) $20 \times$ 25 (Fe 164 kg), pekerjaan beton balok (B4) $15 \times 25 \quad(F e 273 \mathrm{~kg})$, pemasangan batako, pekerjaan plesteran, pekerjaan acian, pekerjaan dinding keramik wc $(20 \times 25)$, pekerjaan lantai keramik wc $(20 \times 20)$, pekerjaan lantai keramik $(40 \times 40)$, pekerjaan cat tembok, pekerjaan water proofing, pemasangan relling tangga jati, pemasangan $\mathrm{mcb} /$ fuce box, pemasangan saklar tunggal, pemasangan saklar double, pemasangan stop kontak, pemasangan bola lampu (18 Watt). Berdasarkan hasil perhitungan diatas diketahui tanggal selesainya proyek konstruksi yaitu 30 juni 2017, hal ini dapat dilihat dari late finish paling lama pada kegiatan kritis. Sehingga waktu yang diperlukan untuk menyelesaikan proyek konstruksi 2 unit rumah dengan menggunakan PDM adalah 150 hari. 


\subsubsection{Analisis dengan Metode LOB}

Analisis dengan menggunakan metode LOB terdapat beberapa langkah yang dilakukan yaitu yang pertama mengidentifikasi setiap kegiatan seperti yang telah dilakukan pada PDM. Langkah kedua menyusun network diagram berdasarkan hubungan ketergantungan yang telah diketahui, selanjutnya menentukan jumlah tenaga kerja yang digunakan pada masing-masing kegiatan, yang dilanjutkan dengan menentukan kecepatan produksi pada masing-masing kegiatan berdasarkan time schedule yang dimiliki, selanjutnya menentukan kelompok pekerja yang mengerjakan tiap aktivitas dengan mengelompokkan perkerjaan yang mempunyai kriteria yang sama, setelah diketahui kecepatan produksi pada masing-masing kegiatan dan jumlah kelompok yang digunakan dapat diketahui kecepatan produksi total, selanjunya menghitung durasi total untuk menyelesaikan seluruh unit untuk setiap kegiatan, menentukan waktu start dan finish yang baru, yang selanjutnya dapat digambarkan diagram LOB.

\subsubsection{Mengidentifikasi Kegitan pada Proyek}

Seperti yang telah dikerjakan pada PDM, dapat diketahui bahwa daftar kegiatan proyek pada time schedule terdapat 85 kegiatan yang akan dikerjakan untuk satu unit rumah yang akan dibangun.

\subsubsection{Menyusun Network Diagram}

Penyusunan network diagram dilakukan dengan berdasarkan hubungan ketergantungan suatu kegiatan dengan kegiatan lainnya. Penyusunan network diagram sama dengan yang terdapat pada PDM.

\subsubsection{Menentukan Jumlah Tenaga Kerja}

Dalam menentukan jumlah tenaga kerja pada masing-masing kegiatan dilakukan dengan melihat durasi yang terdapat pada time schedule, volume pada $\mathrm{RAB}$, dan koefisisen tukang pada analisa harga satuan SNI. Berikut contoh perhitungan dalam menentukan jumlah tenaga kerja:

Pekerjaan pembersihan:

Volume $=245 \mathrm{~m}^{2}$

Durasi $=4$ hari

koefisien pekerja $=0,1 \mathrm{orang} / \mathrm{m}^{2}$

koefisien mandor $=0,05 \mathrm{orang} / \mathrm{m}^{2}$
Perhitungan jumlah tenaga kerja untuk pekerjaan pembersihan diperoleh hasil sebagai berikut:

$$
\begin{aligned}
& \text { Jumlah pekerja }=\frac{245}{4} \times 0,1 \\
&=6,125 \text { orang/hari } \\
& \text { Jumlah mandor }=\frac{245}{4} \times 0,05 \\
&= 3,0625 \text { orang } \\
& \text { /hari }
\end{aligned}
$$

Sehingga jumlah tenaga kerja yang dibutuhkan untuk pekerjaan pembersihan untuk satu unit rumah adalah 6,125 orang pekerja/ hari dan 3,0625 orang mandor/hari.

\subsubsection{Menentukan Kecepatan Produksi untuk Setiap Kegiatan}

Berdasarkan durasi yang telah diperoleh dari time schedule, dapat diketahui kecepatan produksi untuk masing-masing aktivitas dengan 1 kelompok pekerja. Berikut contoh perhitungan untuk pekerjaan pembersihan dalam menentukan kecepatan produksi:

Pekerjaan pembersihan:

Durasi $=4$ hari

Kecepatan produksi $=\frac{1}{4}=0,25$ unit $/$ hari

\subsubsection{Menentukan Jumlah Kelompok Pekerja pada Setiap Kegiatan}

Penentuan jumlah kelompok pekerja yang digunakan, dibuat dengan mengasumsikan kelompok tenaga kerja berdasarkan pekerjaan yang memiliki kriteria yang sama. Asumsi yang digunakan yaitu jumlah mandor dalam suatu kelompok kerja merupakan jumlah kelompok kerja yang digunakan. Berikut pengelompokan tenaga kerja berdasarkan kriteria yang sama:

\section{Kelompok Pekerjaan yang Berhubungan dengan Tanah:}

Pekerjaan yang termasuk dalam kelompok pekerjaan yang berhubungan dengan tanah yaitu, pekerjaan pembersihan, pekerjaan galian tanah pondasi menerus, pekerjaan galian tanah pondasi setempat, pekerjaan urugan pasir di bawah pondasi, pekerjaan urugan tanah kembali ditambah pemadatan, pekerjaan urugan pasir di bawah lantai (peninggi lantai).

\section{Kelompok Pekerjaan yang Berhubungan dengan Batu.}

Pekerjaan yang termasuk dalam kelompok pekerjaan yang berhubungan dengan batu yaitu, pemasangan batu kosong, pemasangan batu kali, pemasangan pipa air kotor, pemasangan 
pipa air buangan, pemasangan pipa air bersih (3Y4), pemasangan batako, pemasangan bak mandi, pemasangan kloset, pemasangan floor drain, pekerjaan plesteran, pemasangan dinding kaca, pemasangan keran air, pemasangan tempat sabun, pekerjaan tembok penyengker, pekerjaan pilar tembok penyengker, pekerjaan apit surang, pekerjaan acian, pemasangan sepptictank, pekerjaan dinding keramik wc $(20 \times 25)$, pekerjaan lantai keramik wc $(20 \times 20)$, pekerjaan lantai keramik $(40 \times$ 40), pekerjaan plain keramik $15 \times 40$, pelinggih padmasari.

\section{Kelompok Pekerjaan yang Berhubungan dengan Beton.}

Pekerjaan yang termasuk dalam kelompok pekerjaan yang berhubungan dengan beton yaitu, pekerjaan beton rabat dan lantai kerja 1:3: 5 , pekerjaan beton foot plat $1(F e 51)$, pekerjaan beton foot plat 2 ( $\mathrm{Fe}$ 52), pekerjaan beton slooft (S1) $25 \times 30 \quad(F e 118 \mathrm{~kg})$, pekerjaan beton slooft (S2) $15 \times 20$ $(F e 158 \mathrm{~kg})$, pekerjaan beton kolom $(K 1) 25 \times 25$ (Fe $217 \mathrm{~kg}$ ), pekerjaan beton kolom (K2) $13 \times 13(F e 210 \mathrm{~kg})$, pekerjaan beton balok (B1) $25 \times 40(\mathrm{Fe} 176 \mathrm{~kg})$, pekerjaan beton balok (B2) $20 \times 30(F e 251 \mathrm{~kg})$, pekerjaan beton plat lantai $K .120(F e 116 \mathrm{~kg})$, pekerjaan beton kolom (K3) $13 \times 20$ (Fe $279 \mathrm{~kg})$, pekerjaan beton kolom $(K 4) \quad 25 \times$ 25 (Fe $151 \mathrm{~kg})$, pekerjaan beton kolom (K5) $13 \times 20(F e 288 \mathrm{~kg})$, pekerjaan beton plat tangga luar $K .100(F e 225 \mathrm{~kg})$, pekerjaan beton plat tangga dalam $K .100(\mathrm{Fe} 86 \mathrm{~kg})$, pekerjaan beton balok (B3) $20 \times 25$ (Fe $164 \mathrm{~kg}$ ), pekerjaan beton balok (B4) $15 \times$ 25 (Fe $273 \mathrm{~kg}$ ), pekerjaan beton plat lisplank $(F e 107 \mathrm{~kg})$, pekerjaan beton plat atap $K .100(\mathrm{Fe} 83 \mathrm{~kg})$, pekerjaan beton ring balok $15 \times 20(\mathrm{Fe} 231 \mathrm{~kg})$.

\section{Kelompok Pekerjaan yang Berhubungan dengan Kayu.}

Pekerjaan yang termasuk dalam kelompok pekerjaan yang berhubungan dengan kayu yaitu, pemasangan bowplank, pemasangan rangka kuda-kuda, pekerjaan kusen pintu jendela, pemasangan usuk $4 / 6$, pemasangan ventilasi, pemasangan engsel pintu, pemasangan engsel jendela, pemasangan pintu $\mathrm{P} 1$, pemasangan pintu $\mathrm{P} 2$, pemasangan pintu $\mathrm{P} 3$, pemasangan pintu jendela $\mathrm{PJ} 1$, pemasangan jendela $\mathbf{J} 1$, pemasangan jendela $\mathbf{J} 2$, pemasangan kait angin jendela, pemasangan grendel jendela, pemasangan pintu kaca, pemasangan reng kayu kamper $2 / 3$, pemasangan kunci pintu kamar mandi, pemasangan kunci pintu, pemasangan genteng plentong besar, pemasangan tatab, pemasangan lisplank $2 \times 15$, pemasangan bubungan pletong besar, pemasangan murda, pemasangan ikut celedu, pekerjaan pintu besi, pemasangan relling tangga jati.

\section{Kelompok Pekerjaan yang Berhubungan dengan Listrik.}

Pekerjaan yang termasuk dalam kelompok pekerjaan yang berhubungan dengan listrik yaitu, pemasangan $\mathrm{MCB} /$ fuce box, pemasangan saklar tunggal, pemasangan saklar double, pemasangan stop kontak, pemasangan bola lampu (18 watt).

\section{Kelompok Pekerjaan yang Berhubungan dengan Cat.}

Pekerjaan yang termasuk dalam kelompok pekerjaan yang berhubungan dengan cat yaitu, pekerjaan cat tembok, pekerjaan cat plapon, pekerjaan politur, pekerjaan water proofing.

Berdasarkan tabel pengelompokan tenaga kerja, dapat diketahui jumlah kelompok pekerja pada pekerjaan yang berhubungan dengan tanah yaitu 4 kelompok pekerja, kelompok pekerja pada pekerjaan yang berhubungan dengan batu yaitu 7 kelompok pekerja, kelompok pekerja pada pekerjaan yang berhubungan dengan beton yaitu 2 kelompok pekerja, kelompok pekerja pada pekerjaan yang berhubungan dengan kayu yaitu 3 kelompok pekerja, kelompok pekerja pada pekerjaan yang berhubungan dengan listrik yaitu 1 kelompok pekerja, dan kelompok pekerja pada pekerjaan yang berhubungan dengan cat adalah 1 kelompok pekerja.

\subsubsection{Menentukan Kecepatan Produksi Total Untuk Setiap Aktivitas}

Setelah diperoleh kecepatan produksi untuk setiap kegiatan dengan 1 kelompok pekerja maka diperoleh kecepatan produksi total untuk setiap kegiatan dengan jumlah kelompok pekerja yang digunakan. Berikut contoh perhitungan pekerjaan pembersihan dalam menentukan kecepatan produksi total:

Pekerjaan pembersihan:

Kecepatan produksi $\quad=0,25$ unithari

Jumlah kelompok pekerja $=4$ kelompok pekerja (Kelompok Tanah)

Kecepatan produksi total $=0,25 \times 4$ $=1 \mathrm{unit} / \mathrm{hari}$ 


\subsubsection{Menentukan Durasi Total Untuk Setiap Aktivitas}

Durasi total untuk setiap aktivitas dapat ditentukan menggunakan rumus yaitu;

$$
\text { Durasi total }=\frac{\text { Jumlah unit yang dibangun }}{\text { kecepatan produksi total }}
$$

Berikut contoh perhitungan dalam menentukan durasi total:

Pekerjaan pembersihan:

Kecepatan produksi total $=1 \mathrm{unit} / \mathrm{hari}$

Jumlah unit yang akan dibangun $=2$ unit

Durasi total $=\frac{2}{1}=2$ hari

\subsubsection{Menentukan Waktu Start Dan Finish Untuk Setiap Aktivitas}

Berdasarkan durasi total untuk setiap aktivitas yang telah diperoleh dan mengetahui hubungan ketergantungan antar aktivitas satu dengan aktivitas lainnya, dapat diketahui waktu start dan finish yang baru, berikut contoh menentukan waktu start dan finish yang baru pada pekerjaan pembersihan:

Diketahui durasi total dari pekerjaan pembersihan adalah 2 hari, Karena waktu mulai kegiatan paling awal dianggap nol, jadi perhitungan pekerjaan pembersihan menjadi:

Waktu start $=0$

Waktu finish $=0+2=2$ hari

\subsubsection{Menggambar Diagram Line of Balance}

Pada diagram line of balance sumbu horizontal menunjukkan durasi, sumbu vertikal menunjukkan unit rumah dan garis diagonal antara sumbu horizontal dan sumbu vertikal masing-masing mewakili satu kegiatan, kemiringan garis pada suatu aktivitas menunjukkan tingkat produksi suatu kegiatan (Uher, 2003). Pada penggambaran diagram line of balance jika terdapat garis kegiatan yang berpotongan maka, perpotongan tersebut menunjukkan adanya conflict antara kegitan, conflict terjadi saat suatu kegiatan tidak bisa dimulai karena kegiatan sebelumnya belum selesai sehingga menimbulkan waktu tunggu. Sebagai contoh dapat dilihat pada gambar 2 .

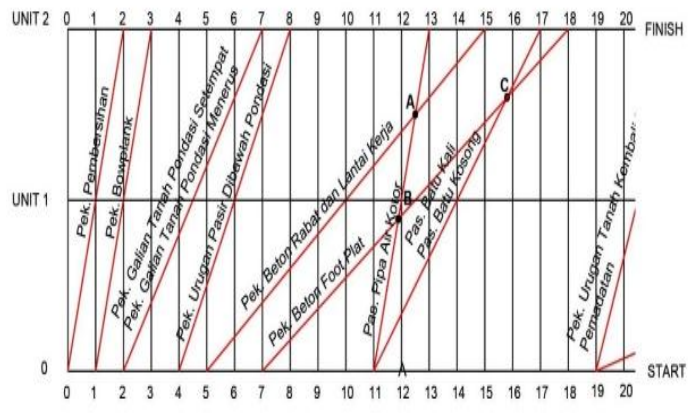

Gambar 2. Diagram LOB

Gambar 2 menunjukkan adanya tiga titik perpotongan garis yaitu titik $\mathrm{A}, \mathrm{B}$, dan $\mathrm{C}$. Perpotongan garis di titik A dan B menunjukkan kegiatan pemasangan pipa air kotor terhambat pengerjaannya karena pekerjaan beton rabat dan lantai kerja dan pekerjaan beton foot plat belum selesai dikerjakan, sehingga pemasangan pipa air kotor dimulai pada hari ke 17 dan direncanakan selesai pada hari ke 19 setelah diberikan buffer time. Perpotongang garis di titik $\mathrm{C}$ menunjukkan pemasangan batu kali dan pemasangan batu kosong terhambat pengerjaannya karena perkerjaan beton foot plat belum selesai dikerjakan, sehingga pemasangan batu kali dan batu kosong diperlambat waktu mulainya menjadi hari ke 12 dan direncanakan selesai pada hari ke 18 . Setelah contoh diagram LOB pada gambar 2 diberikan buffer time, menghasilkan diagram LOB yang tidak terdapat perpotongan garis didalamnya sebagai contoh dapat dilihat pada gambar 3.

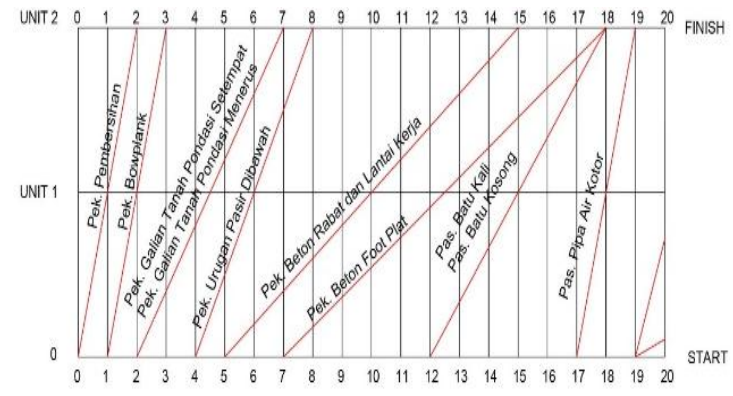

Gambar 3. Diagram LOB

Dari penggambaran diagram line of balance ini diperoleh hasil penyelesaian untuk 2 unit rumah yaitu 143 hari. 


\section{KESIMPULAN DAN SARAN}

Hasil penelitian mengenai penyelesaian proyek pembangunan 2 unit rumah lantai 2 type 62/245 dengan menggunakan PDM dan LOB mendapatkan kesimpulan yaitu:

Waktu penyelesaian proyek pembangunan perumahan lantai 2 type 62/245 untuk dua unit rumah menggunakan metode PDM diperoleh hasil 150 hari sedangkan menggunakan metode LOB waktu yang perlukan selama 143 hari.

Metode PDM membutuhkan waktu yang lebih lama untuk menyelesaikan 2 unit rumah dengan type 62/245 daripada metode LOB, dan pada metode PDM, untuk mengetahui durasi total harus diketahui hubungan ketergantungan pada masing-masing aktivitas untuk seluruh unit yang akan dibangun, sedangkan pada LOB membutuhkan hubungan ketergantungan dari satu unit rumah dari keseluruhan unit yang aka dibangun.

Disarankan untuk penelitian selanjutnya disarankan tidak hanya menghitung waktu tetapi juga biaya.

\section{DAFTAR PUSTAKA}

Hutagaol, J. D., Sendi, S., Wibowo, M. A., \& Santoso, T. D. (2013). Perbandingan Metode Critical Path Method (Cpm),
Precedence Diagram Method (Pdm), Dan Line of Balance (Lob) Terhadap Proyek Repetitif. JURNAL KARYA TEKNIK SIPIL, 2(1), 205-227.

Siang, J. J. 2014. Riset Operasi Algoritmis. (Fl. Sigit Suyantoro, Ed.). Yogyakarta: ANDI YOGYAKARTA.

Sanjaya, D. (2014). Studi Perbandingan Penjadwalan Proyek Metode Line of balance (LoB) Dan Precedencediagram Method (Pdm) Pada Pekerjaan Berulang (Repetitif). Vol. 3, No. 1.

Soeharto, Iman. 1999. MANAJEMEN PROYEK (Dari Konseptual Sampai Operasional). Jakarta: ERLANGGA.

Sugiarti, Ucha Oktavia. 2014. Perbandingan PERT/CPM dan PDM Pada Pengalokasian Waktu. Skripsi. Bukit Jimbaran. Universitas Udayana.

Uher, T. E. (2003). Programming and Scheduling Techniques. UNSW Press.

Veranika, Gusti Ayu Agung Ririn. 2015. Penjadwalan Proyek Kontruksi dengan Perbandingan PERT/CPM dan LOB Terhadap Waktu. Skripsi. Bukit Jimbaran. Universitas Udayana. 